\title{
Editorial
}

\section{Agora: The Internationalists: How a radical plan to outlaw war remade the world}

\section{Introduction}

This journal provides a forum for the publication of cutting-edge scholarship on the foundations, principles, scope and limitations of global constitutionalism. The journal's editors are equally devoted to promoting innovative and interesting ways of presenting scholarship in this inter- and cross-disciplinary field. One non-conventional way of exploring relevant issues that the journal has developed is the publication from time to time of a scholarly 'Agora'. In ancient Greece, the agora was both a public square and a central marketplace. It represented a site where citizens would engage not only in commercial transactions, but also in public debate over 'political' issues. The ancient agora was thus a literal marketplace of ideas. We seek to revive this meaning by creating a scholarly space for dialogue over current and enduring issues of public order and law that take place both within and beyond states.

The point of departure for this agora is an iconoclastic argument developed by Oona A Hathaway and Scott J Shapiro in their monograph The Internationalists: How a Radical Plan to Outlaw War Remade the World. The authors provide a sweeping, and highly readable, survey of several hundred years of international legal doctrine. Their central claim revolves around the significance of the General Treaty for the Renunciation of War, also known as the Paris Peace Pact and the Kellog-Briand Pact. This treaty provided that parties 'condemn recourse to war for the solution of international controversies, and renounce it, as an instrument of national policy in their relations with one another' and that disputes shall be resolved 'by pacific means'.

Many readers may wonder how seriously to take a treaty that outlaws war. Hathaway and Shapiro claim that this oft-derided 1928 treaty in fact symbolises a dramatic break between an 'Old World Order' and a 'New World Order'. In the Old World Order, the initiation of war was a lawful response to wrongs committed by a state. Since war was lawful, it followed that states had the right to conquer other states and occupy their territory, as well as the right to threaten the use of force (i.e., 'gunboat diplomacy'). 
Third party states were to maintain neutrality as between warring states, and not to impose sanctions on the state they considered the wrong doer. In outlawing war, the Peace Pact turned this legal order on its head. In the New World Order, aggressive war is unlawful, as is the threat of force. States have no right to conquer other states or occupy their territory. With war no longer a lawful option, economic and other forms of sanctions become a primary means for inducing states to comply with legal obligations. Thus, the New World Order represents a 'photographic negative' of the Old War Order.

To explore these claims, and their implications, we invited an outstanding interdisciplinary group of scholars from political science, philosophy and law to participate in a live 'agora' at the WZB Berlin Social Science Center in July 2018. In the pages that follow, we present written versions of their reflections and observations, as well as a thoughtful response by Professors Hathaway and Shapiro.

We welcome your reactions to these papers, as well as suggestions for future agorae.

The Editors 